\title{
Growth and Nitrogen Partitioning, Recovery, and Losses in Bermudagrass Receiving Soluble Sources of Labeled ${ }^{15}$ Nitrogen
}

\author{
G.A. Picchioni ${ }^{1}$ and Héctor M. Quiroga-Garza ${ }^{2}$ \\ Department of Agronomy and Horticulture, Box 30003, New Mexico State University, Las Cruces, NM 88003
}

AdDitional INDEX wORDs. Turfgrass nutrition, Cynodon dactylon 'Tifgreen', photoperiod, irradiance, temperature

\begin{abstract}
Two greenhouse studies were conducted to trace the fate of fertilizer $\mathrm{N}$ in hybrid bermudagrass [Cynodon dactylon (L.) Pers. x C. transvaalensis Burtt-Davy 'Tifgreen'], and to estimate total plant $\mathrm{N}$ recovery and losses. The first experiment was performed during winter, with artificial light supplementing natural light to provide a photoperiod of 13.6 to $13.8 \mathrm{hours}$. The second experiment was conducted during summer and fall under only natural light conditions, with a progressively decreasing photoperiod of 13.7 to 11.1 hours. Urea (UR), ammonium sulfate (AS), and ammonium nitrate (AN) were labeled at 2 atom $\%{ }^{15} \mathrm{~N}$, and applied at $\mathrm{N}$ rates of 100 or $200 \mathrm{~kg} \cdot \mathrm{ha}^{-1}$ for 84 days (divided into six equal fractions and applied every 14 days). Fertilizer $N$ source did not affect total dry matter (DM) accumulation by the plant components, but the high $N$ rate increased clipping DM production under the longer photoperiod. Under the decreasing photoperiod, overall DM production was reduced, and clipping DM production was unaffected by increased $\mathrm{N}$ rate. Average $\mathrm{N}$ concentration of clippings varied between N sources, ranging from a high of $38.6 \mathrm{~g} \cdot \mathrm{kg}^{-1} \mathrm{DM}$ with AS to a low of $34.7 \mathrm{~g} \cdot \mathrm{kg}^{-1}$ for UR. In Expt. 1, the greatest total plant $\mathrm{N}$ recovery [clippings, verdure (shoot material remaining after mowing), and thatch plus roots] occurred with AS (78.5\%) and the lowest with UR (65.9\%). In Expt. 2, these values declined to 53.0\% and 38.0\%, respectively. Urea fertilization resulted in the greatest $\mathrm{N}$ losses as a fraction of the $\mathrm{N}$ applied (33.6\% to 61.5\%) and AS fertilization the lowest $(20.7 \%$ to $46.3 \%$ ). In view of the greater $N$ losses, $U R$ may be a less suitable soluble $N$ source for bermudagrass fertilization within the conditions of this study. In addition, late-season $N$ fertilization may result in a significant waste of fertilizer $N$ as bermudagrass progresses into autumnal dormancy when temperature, photoperiod, and irradiance decline and cause reduction in growth and $\mathrm{N}$ uptake.
\end{abstract}

Despite the fact that hybrid bermudagrass (Cynodon dactylon $\mathrm{x}$ C. transvaalensis) is used extensively for ornamental and recreational purposes in the southwestern United States, available information concerning fertilizer $\mathrm{N}$ fate in bermudagrass turf is limited (Petrovick, 1990; Trenholm et al., 1998). Increasing public concern over environmental quality and energy conservation has highlighted the need to investigate Nutilization efficiency in bermudagrass turf plantings, particularly because of the high levels of $\mathrm{N}$ fertilization and irrigation used on this intensively managed crop.

Home lawns, athletic fields, recreational facilities, educational institutions, and industrial settings represent an important fraction of urban and suburban land use, especially in the rapidly expanding metropolitan areas of the southwestern United States, such as New Mexico and Arizona. Both states have a current annual population growth rate two to three times the national average (U.S. Census Bureau, 1999). Intensive use of turfgrass in this region will undoubtedly continue in light of population increases, escalating public interest in recreational opportunities, and the associated (and rarely cited) benefits of turf in erosion control, heat dissipation, and recharge and protection of groundwater (Beard and Green, 1994). However, as significant groundwater recharge in municipal areas occurs through lawns (especially in semiarid regions such as New Mexico and Arizona), there is a major risk of polluting potable drinking water sources by $\mathrm{NO}_{3}$-Nleaching (Exner et al., 1991; Gross et al., 1990).

Received for publication 8 Feb. 1999. Accepted for publication 5 Aug. 1999. This work was supported by state and Hatch Act funds, and Consejo Nacional de Ciencia y Technología (CONACYT, Mexico). The cost of publishing this paper was defrayed in part by the payment of page charges. Under postal regulations, this paper therefore must be hereby marked advertisement solely to indicate this fact.

${ }^{1}$ Assistant professor and corresponding author; e-mail: gpicchio@nmsu.edu.

${ }^{2}$ Former graduate student. Present address: Instituto Nacional de Investigaciones Forestales Agricolas y Pecuarias (INIFAP), Apartado Postal 247, Torreón Coahuila 27000, México; e-mail: hmquiroga@yahoo.com.
Data available on turfgrass fertilizer $\mathrm{N}$ uptake, recovery, and losses are highly variable, and much of the information has been obtained with cool-season grasses. For example, in mixed stands of Kentucky bluegrass (Poa pratensis L.), chewings fescue (Fescue rubra var. commutata Gaud.), and red fescue (Festuca rubra L.), the percentage recovery of applied fertilizer $\mathrm{N}$ in clippings (from readily soluble fertilizer $\mathrm{N}$ sources) has ranged from $20 \%$ to over 50\% (Hesketh et al., 1995; Starr and DeRoo, 1981).

Considering the limited quantitative data on fertilizer $\mathrm{N}$ uptake, recovery, and losses in hybrid bermudagrass turf, our objective was to trace the fate of applied $\mathrm{N}$ fertilizer in bermudagrass grown on a modified sandy medium receiving three soluble $\mathrm{N}$ sources, each applied at two rates, and under constant (long-day) or decreasing (short-day) photoperiodic conditions. We estimated total recovery of applied $\mathrm{N}$ by the plant components and overall $\mathrm{N}$ losses by using a labeled $\mathrm{N}$ source $\left({ }^{15} \mathrm{~N}\right)$, which as with other stable isotopic tracer elements, represents a safe and quantitatively accurate technique for following the movement and recovery of applied fertilizer $\mathrm{N}$ within the root medium-plant system (Bremner and Hauck, 1982).

\section{Materials and Methods}

ENVIRONMENTAL CONDITIONS. Two experiments were conducted, each of $84 \mathrm{~d}$ duration, under greenhouse conditions at the Fabian Garcia Plant Science Center, New Mexico State University, Las Cruces ( $32^{\circ} 16^{\prime} 43.02^{\prime \prime}$ north, $106^{\circ} 46^{\prime} 15.6^{\prime \prime}$ west). The first experiment was conducted from 3 Dec. 1995 to $25 \mathrm{Feb}$. 1996. To increase the photoperiod, artificial light was supplied using high-pressure sodium lamps. Lamps operated from 1630 to $2000 \mathrm{HR}$, providing a photoperiod of 13.6 to $13.8 \mathrm{~h}$. Maximum and minimum greenhouse irradiance at plant level was measured using a quantum sensor (LI89, LI-COR Inc., Lincoln, Nebr.), and ranged from 250 to 300 $\mu \mathrm{mol} \cdot \mathrm{m}^{-2} \cdot \mathrm{s}^{-1}$ (artificial light), and from 550 to $1200 \mu \mathrm{mol} \cdot \mathrm{m}^{-2} \cdot \mathrm{s}^{-1}$ 
(natural light). Greenhouse temperatures ranged from minima of 10.2 to $18.0{ }^{\circ} \mathrm{C}$ and maxima of 21.0 to $36.0^{\circ} \mathrm{C}$ (Fig. 1).

The second experiment was conducted 31 July to 23 Oct. 1996 under natural light conditions only, with a progressively decreasing photoperiod of 13.7 to $11.1 \mathrm{~h}$. Temperature minima ranged from 10.5 to $24.7^{\circ} \mathrm{C}$ and maxima from 27.5 to $37.4^{\circ} \mathrm{C}$. Natural photosynthetic photon flux $(P P F)$ varied between 550 to 1200 $\mu \mathrm{mol} \cdot \mathrm{m}^{-2} \cdot \mathrm{s}^{-1}$.

In both experiments, daily minimum and maximum greenhouse air temperatures were recorded. Daily $P P F$ within the greenhouse was not monitored. Thus, daily accumulated natural radiant energy external to the greenhouse was monitored using a pyranometer (LICOR 200), located within $200 \mathrm{~m}$ of the greenhouse at an official weather station and positioned $2.5 \mathrm{~m}$ above ground. The accumulated radiometric units were converted to quantum units on a 24-h average basis using the technique of Thimijan and Heins (1983). Since $P P F$ was obtained from an outdoor weather station, actual irradiance on the plants was overestimated equally in both experiments by up to $\approx 30 \%$, based on cloudless, midday comparisons between the quantum sensor in the greenhouse and weather station, and based on characteristic light transmission through the greenhouse covering (fiberglass-reinforced plastic; Hanan, 1998).

Cultural Procedures AND Treatments. 'Tifgreen' bermudagrass plugs were washed in water to remove all soil, and roots were trimmed to $5 \mathrm{~cm}$ in length from the thatch layer. Plugs were obtained from sod purchased at a local nursery and cut with pruning shears to a circular size of $15 \mathrm{~cm}$ in diameter and $5 \mathrm{~cm}$ thickness. Single plugs were then planted atop polyvinlychloride cylinders $(15.2 \mathrm{~cm}$ in diameter and $30 \mathrm{~cm}$ in length) which were filled with growing medium (see below; 18 Nov. 1995 for Expt. 1, and 16 July 1996 for Expt. 2), irrigated with tap water, and cut with scissors at a height of $1.5 \mathrm{~cm}$ every $5 \mathrm{~d}$ until the beginning of fertilization treatments.

The cylinder (pot) bottoms were closed with plexiglass, and in the center of each cover, a 1-cm-diameter hole was drilled for drainage purposes. The bottom $2.5 \mathrm{~cm}$ of each pot was filled with coarse gravel, and the remaining space was filled with growing medium consisting of a 3.8-kg mixture of 93 builder's grade sand : 7 peat (w/w). The $\mathrm{N}$ concentration of peat was $7.8 \mathrm{~g} \cdot \mathrm{kg}^{-1}$ dry weight measured as total Kjeldahl N (Gavlak et al., 1994). While this growing medium closely resembles that used for golf course greens, it only approximated field soil conditions. Our primary objective, however, was to use this system to evaluate relative effects of $\mathrm{N}$ rates, sources, and photoperiodic conditions on $\mathrm{N}$ use efficiency.

Deionized water was used for irrigation. A total of 3.5 and $3.7 \mathrm{~L}$ water (20.0 and $20.6 \mathrm{~cm}$ equivalent depth of water) was applied per pot for Expts. 1 and 2, respectively. The leaching fractions [(leached volume $\div$ applied volume $) \times 100$ ] averaged $11.8 \%$ and $13.0 \%$ for Expts. 1 and 2, respectively. Irrigations were applied every other day.

Urea (UR), $\left(\mathrm{NH}_{4}\right)_{2} \mathrm{SO}_{4}(\mathrm{AS})$, and $\mathrm{NH}_{4} \mathrm{NO}_{3}(\mathrm{AN})$ were labeled (2 atom $\%{ }^{15} \mathrm{~N}$ ) and applied at two $\mathrm{N}$ rates, 100 or $200 \mathrm{~kg} \cdot \mathrm{ha}^{-1}$ for $84 \mathrm{~d}$ (equivalent to 10 and $20 \mathrm{~g} \cdot \mathrm{m}^{-2}$ for $84 \mathrm{~d}$, or 3.6 and $7.1 \mathrm{~g} \cdot \mathrm{m}^{-2} \cdot \mathrm{month}^{-1}$, respectively). Nitrogen rates were divided into six equal fractions and applied every $14 \mathrm{~d}$. There were no observable differences in clipping color among the three $\mathrm{N}$ sources and two rates.

For AN, two labeling sites were used, ${ }^{15} \mathrm{NH}_{4} \mathrm{NO}_{3}$ and $\mathrm{NH}_{4}{ }^{15} \mathrm{NO}_{3}$. Both were applied as independent treatments at the same $\mathrm{N}$ rates (100 or $200 \mathrm{~kg} \cdot \mathrm{ha}^{-1}$ for $84 \mathrm{~d}$ ), but at 1 atom $\%{ }^{15} \mathrm{~N}$ each. Thus, there were four $\mathrm{N}$ fertilizer treatments at each rate. Fertilizers were applied in solution, using a graduated pipette. One extra pot per replication without $\mathrm{N}$ fertilizer was used as the reference sample for the bermudagrass natural atom $\%{ }^{15} \mathrm{~N}$, and was sampled at the same time as the N-treated pots. A supplemental nutrient solution (without $\mathrm{N}$ ) was applied (10 mL per pot) every $14 \mathrm{~d}$, and included the following rates $\left(\mathrm{kg} \cdot \mathrm{ha}^{-1}\right)$ for macronutrients $\mathrm{K}(162), \mathrm{P}(128), \mathrm{S}(51)$, $\mathrm{Ca}(45)$, and $\mathrm{Mg}$ (38), plus a complete micronutrient supplementation, as outlined previously (Turner and Hummel, 1992).

Plant measurements and Statistical Design. Clippings (shoots + leaves) were cut with scissors at a height of $1.5 \mathrm{~cm}$ three times every $10 \mathrm{~d}$. There were 22 and 24 cuttings for Expts. 1 and 2, respectively. To remove and collect the clippings, pots were placed horizontally during the cutting process. Clippings were dried at 60 ${ }^{\circ} \mathrm{C}$ for $48 \mathrm{~h}$, weighed, and then ground to pass through a 60-mesh $(0.423-\mathrm{mm})$ screen. Total DM in the clippings, which had been harvested over the 84-d growing period, was obtained by summation of the individual dry weights of clippings described above.

At the end of each experiment, a final clipping was taken and processed as described above, then the plugs were washed and separated into verdure and thatch plus root fractions. Verdure consisted of shoot material remaining after cutting. Thatch plus roots consisted of rhizomes, stolons, true roots, and dead plant tissue. By the end of each 84-d period, roots had reached the bottom of pots and occupied the entire volume of growing medium. All fractions were dried at $60^{\circ} \mathrm{C}$ for $72 \mathrm{~h}$, weighed, and ground as were the clippings. The entire sand-peat growing medium in each pot was mixed thoroughly, and a 5-g subsample was air-dried, ground with a mortar and pestle into a fine powder, then sieved using a 100-mesh $(150-\mu \mathrm{m})$ screen, which is the required soil particle size for ${ }^{15} \mathrm{~N}$ analysis. All the powdered medium passed through the mesh, and a 10-mg subsample was used for analysis.

Total $\mathrm{N}$ and atom $\%{ }^{15} \mathrm{~N}$ concentration in clippings, verdure, thatch plus roots, and medium were measured by a Tracermass Stable Isotope Mass Spectrometer (Europa Scientific Ltd., Crewe, Cheshire, U.K.). All clipping $\mathrm{N}$ determinations (both total $\mathrm{N}$ and fertilizer-derived N) were performed on pooled clipping samples harvested over three successive, 28-d intervals to provide sufficient DM for chemical analysis.

The first experiment was conducted during the winter (December to February), and no temperature gradient was detected across the greenhouse. Thus, Expt. 1 treatments were distributed in a completely randomized design. For Expt. 2, during summer and early fall (July to October), a temperature gradient was generated by the cooling system. Thus, Expt. 2 treatments were distributed in a randomized complete block design. For both experiments, three replications were used (one pot per replication).

For a comparison among the three $\mathrm{N}$ fertilizers, data from the two AN treatments $\left({ }^{15} \mathrm{NH}_{4}\right.$ - and ${ }^{15} \mathrm{NO}_{3}$-labeled molecules) were combined (averaged for DM, total $\mathrm{N}$ concentration, ${ }^{15} \mathrm{~N}$ concentration, total $\mathrm{N}$ yield, and then summed for total ${ }^{15} \mathrm{~N}$ isotopic recovery). Both experiments were analyzed independently as $3 \times 2$ factorials (three $\mathrm{N}$ fertilizers $\times$ two $\mathrm{N}$ rates). Statistical analyses of the two AN treatments were conducted as $2 \times 2$ factorials (two AN treatments $\mathrm{X}$ two rates), omitting data for AS and UR pots. For clipping growth rate analysis, the experiments were analyzed as split plots, with the $\mathrm{N}$ source $\times \mathrm{N}$ rate combination as the main plot, and sampling period as the subplot.

The initial DM and $\mathrm{N}$ yields in clippings, verdure, thatch plus roots, and medium in three randomly selected pots were averaged prior to fertilization treatment, and the average value was subtracted from the treatment values (obtained during fertilization) to obtain $\mathrm{DM}$ and $\mathrm{N}$ yield values attributable to the treatment period. Total $\mathrm{DM}, \mathrm{N}$ concentration, $\mathrm{N}$ yield, percent $\mathrm{N}$ derived from the fertilizer (NDFF), and $\mathrm{N}$ recovered as a percentage of the applied $\mathrm{N}(\mathrm{NR})$ were analyzed for clippings, verdure, thatch plus roots, and growing 
medium (SAS Inst., Inc., 1990). Losses of $\mathrm{N}$ from the system were defined as the fertilizer $\mathrm{N}$ unaccounted for following analyses of plant tissues and growing medium.

Calculations for NDFF, the quantity of fertilizer-derived $\mathrm{N}$ (FDN), and NR were as follows (Janzen et al., 1990):

NDFF $(\%)=\left(\%{ }^{15} \mathrm{~N}\right.$ sample $-\%{ }^{15} \mathrm{~N}$ reference sample $) /\left(\%{ }^{15} \mathrm{~N}\right.$ fertilizer $-\% 15 \mathrm{~N}$ background) $\times 100$

[Eq. 1]

FDN $(\mathrm{g})=\% \mathrm{NDFF} / 100 \times$ Sample $\% \mathrm{~N} / 100 \times \mathrm{DM}(\mathrm{g})$

[Eq. 2]

$\mathrm{NR}(\%)=\mathrm{FDN}(\mathrm{g}) /$ applied $\mathrm{N}$ fertilizer $(\mathrm{g}) \times 100$

[Eq. 3].

The average $\%{ }^{15} \mathrm{~N}$ reference value (as determined by mass spectrometric analysis) was 0.3817 , with a range of 0.3789 to 0.3871 . A value of 0.3663 was used for the $\%{ }^{15} \mathrm{~N}$ background (Janzen et al., 1990).

\section{Results and Discussion}

Gradual changes in greenhouse temperatures and the ambient, 24-h average $P P F$ occurred throughout both experiments (Figs. 1 and 2), reflecting the approaching conditions of spring months (Expt. 1), and progression from late summer into autumnal conditions (Expt. 2). Throughout most of the 84-d duration (e.g., $\approx 70 \mathrm{~d}$ ), greenhouse temperatures and average 24-h irradiance were greater in Expt. 2 (short-day conditions) as compared with Expt. 1 (constant long-day conditions).

With few exceptions (as noted below for thatch plus roots in Expt. 2), there were no $\mathrm{N}$ source $\times$ rate interactions, thus $\mathrm{N}$ source averages were pooled across rates and rates across sources.

DRY MATTER. Total clipping, verdure, and thatch plus root DM production (following $84 \mathrm{~d}$ treatment) did not differ among the three soluble $\mathrm{N}$ sources (Table 1 ). The only significant effect of $\mathrm{N}$ rate on total DM accumulation of the various plant components occurred with clipping growth during Expt. 1, being 54\% greater using $\mathrm{N}$ at 200 than at $100 \mathrm{~kg} \cdot \mathrm{ha}^{-1}$ for $84 \mathrm{~d}$. Also, the interaction source $\times$ rate for total thatch plus root DM gain was significant only for Expt. 2, with each source showing a different trend. Thatch plus root growth either increased (AS), decreased (UR), or remained unchanged (AN) with increased $\mathrm{N}$ rate (data not presented).

Clipping growth rate (CliGR) was plotted at 3-d intervals and averaged to obtain DM gains on a per-day basis (Fig. 3). The marked effects of greenhouse conditions, particularly photoperiod (Gaussoin et al., 1988; Marousky et al., 1992), were reflected in the variation in CliGR between each experiment. In Expt. 1, with a near-constant photoperiod of 13.6 to $13.8 \mathrm{~h}$ combined with lower temperature and average 24-h $P P F$, bermudagrass showed a cyclic CliGR pattern in response to $\mathrm{N}$ availability and depletion, with a general increase in $\mathrm{DM}$ accumulation rate over time, particularly at the higher $\mathrm{N}$ rate. Differences in CliGR between the $\mathrm{N}$ rates were widened noticeably from day 56 and beyond, probably because the root system had developed more extensively and average greenhouse temperatures had increased (Fig. 1). After the first, third, fifth, and sixth fertilizer applications (days 0, 28,56, and 70, respectively), large incremental increases in CliGR occurred. However, only a marginal clipping growth response was noted following the second and fourth fertilizer applications (days 14 and 42). This may have been attributed to the $3 \mathrm{~d}$ of relatively low daytime maximum temperatures leading up to day 14 (Fig. 1), cloudy days between days 14 and 28 (Fig. 2), and an extended period of relatively low minimum temperatures between days 42 and 56 (Fig. 1).

The second experiment started at a photoperiod of $13.7 \mathrm{~h}$ and ended at $11.1 \mathrm{~h}$. There was no indication of a gradually increasing growth rate as would be expected in rapidly establishing and

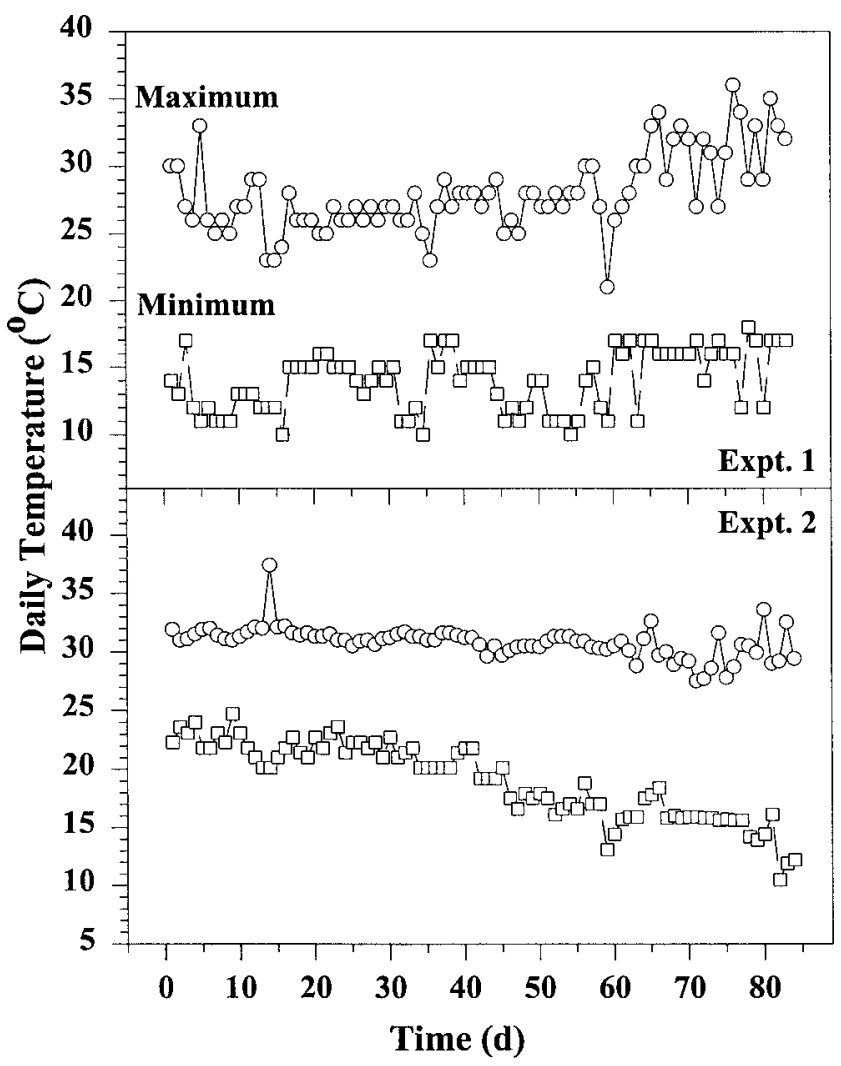

Fig. 1. Maximum and minimum greenhouse air temperatures during Expt. 1 (3 Dec. 1995 to 25 Feb. 1996) and Expt. 2 (31 July to 23 Oct. 1996).

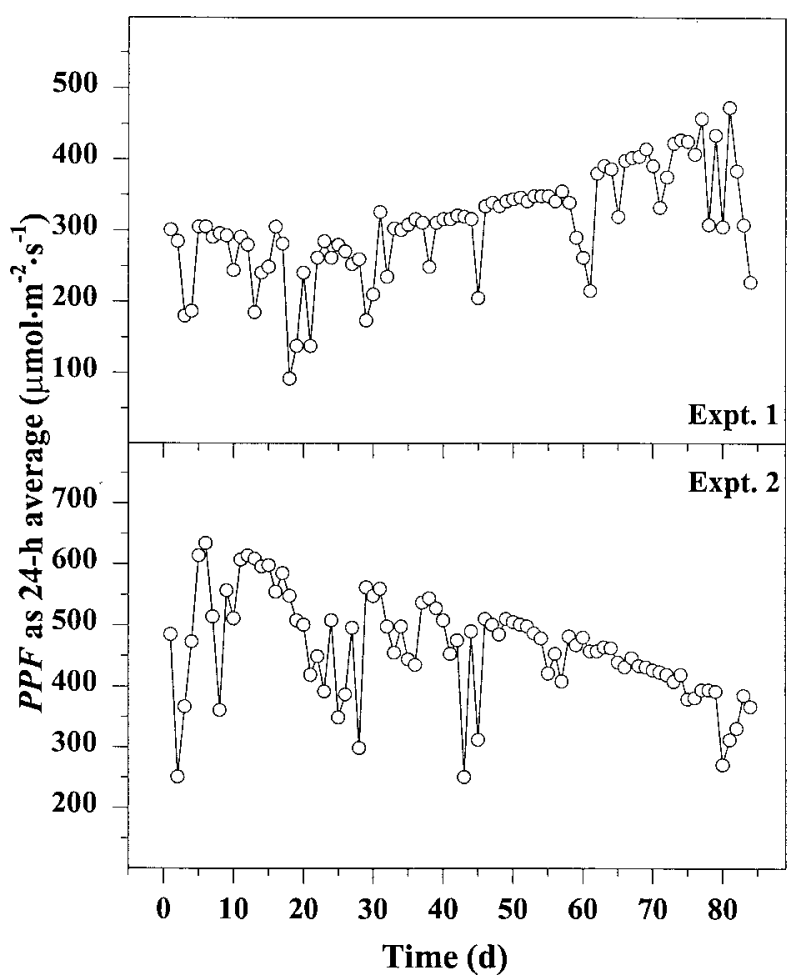

Fig. 2. Photosynthetic photon flux $(P P F)$ of ambient sunlight external to the greenhouse during Expt. 1 (3 Dec. 1995 to 25 Feb. 1996) and Expt. 2 (31 July to 23 Oct. 1996). Each point is the daily 24-h average $P P F$ and includes supplemental interior greenhouse lighting (Expt. 1 only) equivalent to 40 $\mu \mathrm{mol} \cdot \mathrm{m}^{-2} \cdot \mathrm{s}^{-1}$ on a $24-\mathrm{h}$ basis 
Table 1. Total clipping, verdure, and thatch plus root dry matter accumulation in 'Tifgreen' hybrid bermudagrass following fertilization for $84 \mathrm{~d}$ with soluble sources of labeled ${ }^{15} \mathrm{~N} .{ }^{\mathrm{z}}$

\begin{tabular}{|c|c|c|c|c|c|c|}
\hline \multirow{3}{*}{$\begin{array}{l}\text { Main } \\
\text { factor }\end{array}$} & \multicolumn{6}{|c|}{ Dry matter $\left(\mathrm{g} \cdot \mathrm{m}^{-2}\right)$} \\
\hline & \multicolumn{2}{|c|}{ Clippings } & \multicolumn{2}{|c|}{ Verdure } & \multicolumn{2}{|c|}{ Thatch + roots } \\
\hline & Expt. 1 & Expt. 2 & Expt. 1 & Expt. 2 & Expt. 1 & Expt. 2 \\
\hline \multicolumn{7}{|c|}{$\mathrm{N}$ source $^{\mathrm{y}}$} \\
\hline AS & $178.9 \mathrm{a}^{\mathrm{x}}$ & $158.5 \mathrm{a}$ & $231.9 \mathrm{a}$ & $86.7 \mathrm{a}$ & $903.1 \mathrm{a}$ & $622.6 \mathrm{a}$ \\
\hline UR & $159.3 \mathrm{a}$ & $128.0 \mathrm{a}$ & $222.5 \mathrm{a}$ & $118.7 \mathrm{a}$ & $782.1 \mathrm{a}$ & $510.5 \mathrm{a}$ \\
\hline AN & $169.6 \mathrm{a}$ & $150.2 \mathrm{a}$ & $230.5 \mathrm{a}$ & $79.7 \mathrm{a}$ & $727.3 \mathrm{a}$ & $483.2 \mathrm{a}$ \\
\hline \multicolumn{7}{|l|}{$\mathrm{N}$ rate $^{\mathrm{w}}$} \\
\hline 100 & $133.2 \mathrm{~b}$ & $133.9 \mathrm{a}$ & $214.0 \mathrm{a}$ & $101.6 \mathrm{a}$ & $821.1 \mathrm{a}$ & $548.8 \mathrm{a}$ \\
\hline 200 & $205.4 \mathrm{a}$ & $157.0 \mathrm{a}$ & $242.6 \mathrm{a}$ & $90.2 \mathrm{a}$ & $787.2 \mathrm{a}$ & $539.7 \mathrm{a}$ \\
\hline
\end{tabular}

${ }^{\mathrm{z} V a l u e s}$ are the means of three, one-pot replications.

${ }^{\mathrm{y}} \mathrm{AS}=$ ammonium sulfate, $\mathrm{UR}=$ urea, and $\mathrm{AN}=$ ammonium nitrate.

${ }^{x}$ Mean separation within columns for $\mathrm{N}$ source or rate by Tukey's studentized range test, $P<0.05$.

${ }^{\mathrm{w}} \mathrm{kg} \cdot \mathrm{ha}^{-1}$ for $84 \mathrm{~d}$.

growing turf, such as was demonstrated in Expt. 1. In addition, the cyclic pattern of CliGR, occurring in response to $\mathrm{N}$ application and depletion, was evident only at the beginning of the experiment and then began to diminish as early as day 28 (Fig. 3). Subsequent to day 28 , the capacity to respond to $\mathrm{N}$ fertilization may have been limited by the declining photoperiod, since during this time, greenhouse temperatures and ambient irradiance were more favorable for growth in Expt. 2 than in Expt. 1 (Figs. 1 and 2).

CliGR values for 'Tifgreen' bermudagrass (Fig. 3) were several orders of magnitude greater than 'FloraDwarf' and 'Tifdwarf' bermudagrass CliGR values reported in a greenhouse study on a coarse sandy medium by Trenholm et al. (1998) using comparable $\mathrm{N}$ application rates, experimental duration, and ranges of irradiance ( $\mathrm{N}$ at 1 to $10 \mathrm{~g} \cdot \mathrm{m}^{-2} \cdot \mathrm{month}^{-1}, 3$ to 4 months, and 950 to 1212 $\mu \mathrm{mol} \cdot \mathrm{m}^{-2} \cdot \mathrm{s}^{-1}$, respectively), with a higher average greenhouse temperature of $34^{\circ} \mathrm{C}$. They established that a 13 -h photoperiod was the threshold at or about which bermudagrass CliGR increased in response to $\mathrm{N}$ fertilization, which corresponds to our findings in Expt. 2 (Fig. 3).

In addition to genotypic differences in growth (and presumably $\mathrm{N}$ demand) of bermudagrass hybrids in similar experimental conditions, an exception must also be made for differences in experimental conditions for a given bermudagrass cultivar. For example, in semiarid outdoor conditions, McCaslin et al. (1989) recorded an average CliGR of $\approx 1 \mathrm{~g} \cdot \mathrm{m}^{-2} \cdot \mathrm{d}^{-1}$ of DM for 'Tifgreen' (estimated using total clipping dry weight accumulated following a 6-month duration) at a N application rate of $0.16 \mathrm{~g} \cdot \mathrm{m}^{-2} \cdot \mathrm{d}^{-1}$, which is within the $\mathrm{N}$ application range of the current study $\left(0.12\right.$ to $\left.0.24 \mathrm{~g} \cdot \mathrm{m}^{-2} \cdot \mathrm{d}^{-1}\right)$. Our higher CliGR for 'Tifgreen' averaged $\approx 2 \mathrm{~g} \cdot \mathrm{m}^{-2} \cdot \mathrm{d}^{-1}$ of DM based on the totals in Table 1, probably because of a more optimal growing environment in the greenhouse than outdoors.

Total N CONCENTRATION AND YIELD. Clippings were the only plant component where the total $\mathrm{N}$ concentration depended on $\mathrm{N}$ source (Table 2). In each experiment, clipping $\mathrm{N}$ concentration from pots fertilized with AS was $\approx 3$ to $4 \mathrm{~g} \cdot \mathrm{kg}^{-1} \mathrm{DM}$ higher than with AN and UR. With one exception (verdure in Expt. 2), tissue $\mathrm{N}$ concentration increased with $\mathrm{N}$ rate (Table 2).

During Expt. 2, an interaction (source $\times$ rate) for thatch plus root $\mathrm{N}$ concentration was observed. With increased $\mathrm{N}$ rate, AS did not increase thatch plus root $\mathrm{N}$ concentration, whereas increasing the rate of $\mathrm{UR}$ and $\mathrm{AN}$ increased thatch plus root $\mathrm{N}$ concentration (data not shown).

Nitrogen source affected $\mathrm{N}$ yield in clippings but not in verdure and thatch plus roots (Table 2). Clipping $\mathrm{N}$ yield was greatest with
AS and least with UR, while clipping $\mathrm{N}$ yield with $\mathrm{AN}$ was intermediate. Also, increasing $\mathrm{N}$ rate increased $\mathrm{N}$ yield in clippings (both experiments) and in verdure (Expt. 1 only). In another study involving 'Tifgreen' bermudagrass under fertigation, $\mathrm{NH}_{4}$-formulated fertilizer produced greater clipping $\mathrm{DM}$ and $\mathrm{N}$ yield compared to $\mathrm{NO}_{3}$-formulated fertilizer, but no differences in clipping $\mathrm{N}$ concentration(Snyder and Burt, 1985). Generally, we did not observe these effects

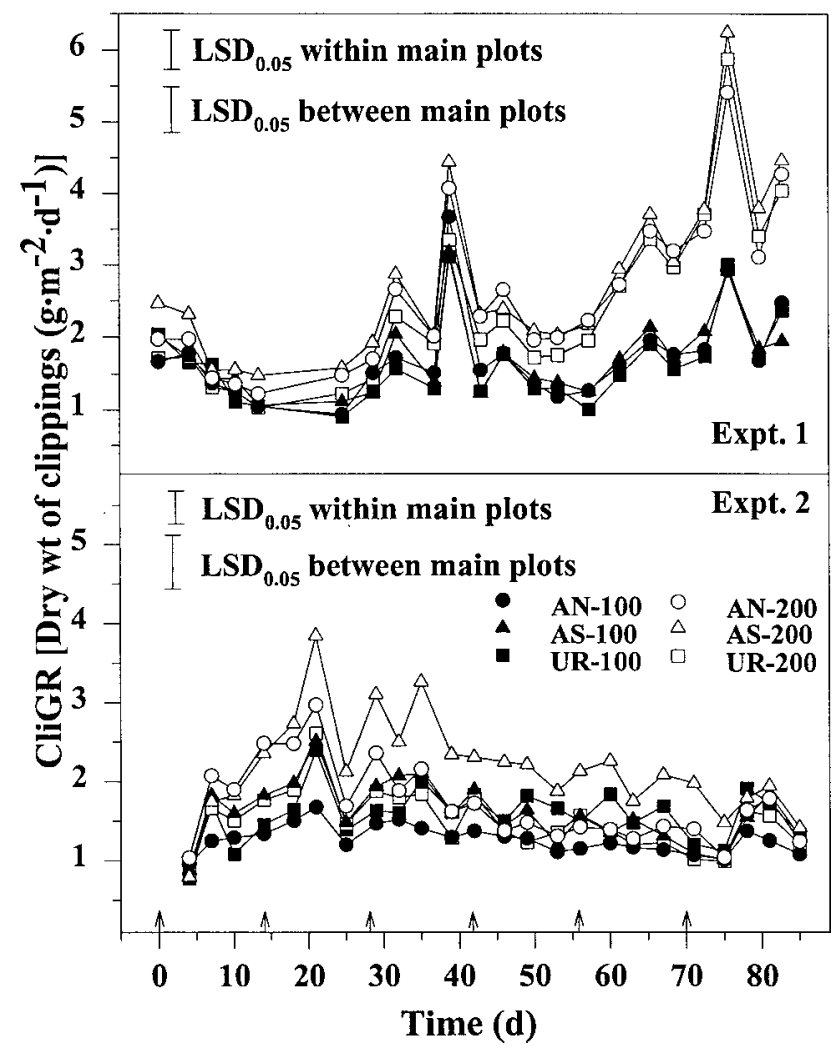

Fig. 3. Clipping growth rate (CliGR) of 'Tifgreen' hybrid bermudagrass fertilized with soluble sources of labeled ${ }^{15} \mathrm{~N}$ : ammonium nitrate (AN), ammonium sulfate (AS), and urea (UR), each applied at $\mathrm{N}$ rates of 100 or $200 \mathrm{~kg} \cdot \mathrm{ha}^{-1}$ for $84 \mathrm{~d}$. Arrows represent the time of fertilizer applications at $0,14,28,42,56$, and 70 d. Each symbol represents the average dry matter (DM) accumulation per day over a 3 to $4 \mathrm{~d}$ average interval for three, one-pot replications. Bars represent the LSD values obtained from the analysis of variance for within main plot comparisons (each $\mathrm{N}$ source and rate treatment combination across days) and between main plot comparisons ( $\mathrm{N}$ source and rate treatment combinations within days). 
in the current study when comparing AS and AN.

FerTiLIZER N RECOVERY AND LOSS. In both experiments, $\mathrm{N}$ source and rate had a significant effect on clipping NDFF (Table 3). Both AN and AS provided greater clipping NDFF values than UR. Also, clipping NDFF increased with $\mathrm{N}$ rate and was greater in Expt. 1 than in Expt. 2. With the AN treatments in both experiments, $\approx 6 \%$ to $7 \%$ greater clipping NDFF was obtained when the fertilizer was labeled as $\mathrm{NO}_{3}$ than when the fertilizer was labeled as $\mathrm{NH}_{4}$.

During Expt. 1, a significant difference among the three $\mathrm{N}$ sources was found for NDFF in verdure (Table 3). Fertilization with AN resulted in more NDFF than UR. As with clippings, a slightly greater proportion of NDFF in verdure was noted from labeled $\mathrm{NO}_{3}$ applied as AN (Expt. 1), but ${ }^{15} \mathrm{~N}$-isotopic enrichment in verdure was divided evenly between $\mathrm{NH}_{4}$ and $\mathrm{NO}_{3}$ during Expt. 2. Increasing $\mathrm{N}$ rate increased verdure NDFF only during Expt. 1, and as with clippings, more NDFF was recovered in Expt. 1 than in Expt. 2.

Nitrogen sources did not affect thatch plus root NDFF, but the higher $\mathrm{N}$ rate increased NDFF in these tissues (Table 3 ). In both experiments, $\mathrm{NDFF}$ for $\mathrm{AN}$ was equal when labeled as $\mathrm{NO}_{3}$ or $\mathrm{NH}_{4}$. In contrast to clippings and verdure, there was slightly more thatch plus root NDFF during Expt. 2.

In Kentucky bluegrass and perennial ryegrass (Lolium perenne L.), there appears to be little or no preference for $\mathrm{NO}_{3}$ or $\mathrm{NH}_{4}$ in $\mathrm{N}$ uptake (Bowman et al., 1989). In our study on bermudagrass, the tendency for greater $\mathrm{NR}$ from $\mathrm{AN}$ labeled as $\mathrm{NO}_{3}$ (compared to $\mathrm{AN}$ labeled as $\mathrm{NH}_{4}$ ), particularly in clippings (Table 3), may suggest preferential $\mathrm{NO}_{3}$ uptake over $\mathrm{NH}_{4}$.

The $\mathrm{N}$ source-related trends found with NR were very similar to those of NDFF(Table 3 ). More labeled $\mathrm{N}$ was recovered in clippings when AN and AS were used as $\mathrm{N}$ sources than when UR was applied. Also, clipping NR increased at the high $\mathrm{N}$ rate in Expt. 1. According to McCaslin et al. (1989), the standard N rate for bermudagrass turf is $\approx 50 \mathrm{~kg} \cdot \mathrm{ha}^{-1} \cdot \mathrm{month}^{-1}$. Our rates (monthly basis) were $\approx 35$ and $70 \mathrm{~kg} \cdot \mathrm{ha}^{-1} \cdot \mathrm{month}^{-1}\left(100\right.$ and $200 \mathrm{~kg} \cdot \mathrm{ha}^{-1}$ for $84 \mathrm{~d}$ rates, respectively). The increased clipping NR with higher $\mathrm{N}$ rate in Expt.
1 is contrary to the general observation of reduced NR (efficiency) as N rates increase (Hesketh et al., 1995). Increased N rate increased CliGR in Expt. 1 (Table 1 and Fig. 3), thus possibly, the higher N rate resulted in a closer-to-optimum available $\mathrm{N}$ level, leading to the increased clipping growth capacity, and correspondingly increased $\mathrm{N}$ uptake efficiency (Bowman et al., 1989).

Our clipping NR values during Expt. 1 were similar to those for Kentucky bluegrass and for mixed cool-season turfgrass stands (20\% to 33\% NR in clippings) receiving labeled urea or $\left(\mathrm{NH}_{4}\right)_{2} \mathrm{SO}_{4}$ (Joo et al., 1991; Miltner et al., 1996; Starr and DeRoo, 1981). In clippings, we recovered between $26 \%$ and $34 \%$ of the labeled $\mathrm{N}$ applied during Expt. 1 and between $17 \%$ and 27\% in Expt. 2. The low clipping NR during Expt. 2 may have been caused by the lessthan-optimum shorter photoperiods on bermudagrass growth and $\mathrm{N}$ demand (Marousky et al., 1992).

Verdure NR during Expt. 2 (decreasing photoperiod) averaged $13 \%$ to $15 \%$ less than in Expt. 1 (Table 3). This paralleled the 58\% average loss in verdure DM production during Expt. 2 (Table 1), which is consistent with the finding that shortening photoperiods lead to reduced leaf extension rates in bermudagrass (Marousky et al., 1992). The reduced verdure and clipping NR during Expt. 2 may also have been related to chlorophyll degradation which accompanies the onset of dormancy in bermudagrass (Youngner, 1959). During declining photoperiods, senescence-related Nremobilization from leaves (clippings) and verdure to perennial structures, such as rhizomes and stolons, was visually manifested as leaf chlorosis. Thus, the export of $\mathrm{N}$ from both leaves and verdure probably contributed to the low NR in these tissues in Expt. 2.

Thatch plus root NR was unaffected by $\mathrm{N}$ source and rate. Thatch plus roots recovered similar amounts of the labeled $\mathrm{N}$ as did verdure in Expt. 1, but the thatch plus root NR declined to a lesser extent in Expt. 2, probably because of the preferential allocation of $\mathrm{N}$ to roots, rhizomes, and stolons as the grass moves into the dormant period (Marschner, 1995).

Of the three $\mathrm{N}$ sources, AS and AN provided the highest total

Table 2. Average $\mathrm{N}$ concentration and total $\mathrm{N}$ yield (labeled and nonlabeled) in clippings, verdure, and thatch plus roots of 'Tifgreen' hybrid bermudagrass fertilized with soluble sources of labeled ${ }^{15} \mathrm{~N}$. Clipping $\mathrm{N}$ concentrations were determined as the average value in pooled clippings over three successive, 28-d intervals, and the clipping $\mathrm{N}$ yields ( $84 \mathrm{~d}$ ) were then totaled over the three periods as the product of dry matter (DM) and $\mathrm{N}$ concentration. Verdure and thatch plus root $\mathrm{N}$ concentrations were determined at the end of $84 \mathrm{~d}$, and their $\mathrm{N}$ yields as the product of DM and $\mathrm{N}$ concentration. ${ }^{\mathrm{z}}$

\begin{tabular}{|c|c|c|c|c|c|c|}
\hline \multirow{2}{*}{$\begin{array}{l}\text { Main } \\
\text { factor }\end{array}$} & \multicolumn{2}{|c|}{ Clippings } & \multicolumn{2}{|c|}{ Verdure } & \multicolumn{2}{|c|}{ Thatch + roots } \\
\hline & Expt. 1 & Expt. 2 & Expt. 1 & Expt. 2 & Expt. 1 & Expt. 2 \\
\hline$\overline{\mathrm{N} \text { source }}{ }^{\mathrm{y}}$ & \multicolumn{6}{|c|}{$\mathrm{N}$ concn $\left(\mathrm{g} \cdot \mathrm{kg}^{-1} \mathrm{DM}\right)$} \\
\hline AS & $39.5 \mathrm{a}^{\mathrm{x}}$ & $37.7 \mathrm{a}$ & $19.5 \mathrm{a}$ & $19.9 \mathrm{a}$ & $11.6 \mathrm{a}$ & $13.5 \mathrm{a}$ \\
\hline UR & $36.1 \mathrm{~b}$ & $33.3 \mathrm{~b}$ & $19.5 \mathrm{a}$ & $17.8 \mathrm{a}$ & $11.9 \mathrm{a}$ & $12.6 \mathrm{a}$ \\
\hline AN & $36.9 \mathrm{~b}$ & $33.9 \mathrm{ab}$ & $19.6 \mathrm{a}$ & $21.3 \mathrm{a}$ & $11.5 \mathrm{a}$ & $12.8 \mathrm{a}$ \\
\hline \multicolumn{7}{|l|}{$\mathrm{N}$ rate $^{\mathrm{w}}$} \\
\hline 100 & $32.0 \mathrm{~b}$ & $32.7 \mathrm{~b}$ & $16.9 \mathrm{~b}$ & $18.1 \mathrm{a}$ & $11.0 \mathrm{~b}$ & $12.0 \mathrm{~b}$ \\
\hline 200 & $41.2 \mathrm{a}$ & $37.4 \mathrm{a}$ & $22.0 \mathrm{a}$ & $21.0 \mathrm{a}$ & $12.3 \mathrm{a}$ & $13.9 \mathrm{a}$ \\
\hline N source & \multicolumn{6}{|c|}{$\mathrm{N}$ yield $\left(\mathrm{g} \cdot \mathrm{m}^{-2}\right)$} \\
\hline AS & $7.1 \mathrm{a}$ & $6.0 \mathrm{a}$ & $4.5 \mathrm{a}$ & $1.7 \mathrm{a}$ & $10.5 \mathrm{a}$ & $8.4 \mathrm{a}$ \\
\hline UR & $5.8 \mathrm{~b}$ & $4.3 \mathrm{~b}$ & $4.4 \mathrm{a}$ & $2.1 \mathrm{a}$ & $9.3 \mathrm{a}$ & $6.4 \mathrm{a}$ \\
\hline AN & $6.3 \mathrm{ab}$ & $5.1 \mathrm{ab}$ & $4.5 \mathrm{a}$ & $1.7 \mathrm{a}$ & $8.4 \mathrm{a}$ & $6.2 \mathrm{a}$ \\
\hline \multicolumn{7}{|l|}{$\mathrm{N}$ rate } \\
\hline 100 & $4.3 \mathrm{~b}$ & $4.4 \mathrm{~b}$ & $3.6 \mathrm{~b}$ & $1.8 \mathrm{a}$ & $10.0 \mathrm{a}$ & $6.6 \mathrm{a}$ \\
\hline 200 & $8.5 \mathrm{a}$ & $5.9 \mathrm{a}$ & $5.3 \mathrm{a}$ & $1.9 \mathrm{a}$ & $9.7 \mathrm{a}$ & $7.5 \mathrm{a}$ \\
\hline
\end{tabular}

$\overline{\mathrm{z}}$ Values are the means of three, one-pot replications.

${ }^{\mathrm{y}} \mathrm{AS}=$ ammonium sulfate, $\mathrm{UR}=$ urea, and $\mathrm{AN}=$ ammonium nitrate.

xMean separation within columns for $\mathrm{N}$ source or rate by Tukey's studentized range test, $P<0.05$.

${ }^{\mathrm{w}} \mathrm{kg} \cdot \mathrm{ha}^{-1}$ for $84 \mathrm{~d}$. 
Table 3. Percentage of $\mathrm{N}$ derived from fertilizer (NDFF) and the accumulated $\mathrm{N}$ recovery (NR) in clippings, verdure, and thatch plus roots of 'Tifgreen' hybrid bermudagrass fertilized with soluble sources of labeled ${ }^{15} \mathrm{~N}$. Clipping NDFF percentages (Eq. 1) were determined as the average NDFF value in pooled clippings over three successive, 28-d intervals, and clipping NR percentages ( $84 \mathrm{~d}$ ) were then totaled over the three periods (Eqs. 2 and 3). Verdure and thatch plus root NDFF values were determined at the end of $84 \mathrm{~d}$, and their NR values determined as in Eqs. 2 and 3. Nitrogen recovery expressed as a percentage of the applied fertilizer N. ${ }^{\mathrm{z}}$

\begin{tabular}{|c|c|c|c|c|c|c|}
\hline \multirow{2}{*}{$\begin{array}{l}\text { Main } \\
\text { factor }\end{array}$} & \multicolumn{2}{|c|}{ Clippings } & \multicolumn{2}{|c|}{ Verdure } & \multicolumn{2}{|c|}{ Thatch + roots } \\
\hline & Expt. 1 & Expt. 2 & Expt. 1 & Expt. 2 & Expt. 1 & Expt. 2 \\
\hline $\mathrm{N}_{\text {source }}{ }^{\mathrm{y}}$ & \multicolumn{6}{|c|}{ NDFF $(\%)$} \\
\hline AN & $77.7 \mathrm{a}^{\mathrm{x}}$ & $66.6 \mathrm{a}$ & 76.7 a & $68.8 \mathrm{a}$ & $33.7 \mathrm{a}$ & $35.1 \mathrm{a}$ \\
\hline$\left(\mathrm{NO}_{3}\right)$ & $(42.6) \mathrm{a}$ & $(36.5) \mathrm{a}$ & $(42.5) \mathrm{a}$ & $(35.6) \mathrm{a}$ & (16.6) a & $(16.3) \mathrm{a}$ \\
\hline$\left(\mathrm{NH}_{4}\right)$ & $(35.1) \mathrm{b}$ & $(30.1) b$ & $(34.2) \mathrm{b}$ & $(33.2) \mathrm{a}$ & $(17.1) \mathrm{a}$ & $(18.8) \mathrm{a}$ \\
\hline $\mathrm{AS}$ & $74.1 \mathrm{a}$ & $65.5 \mathrm{a}$ & $73.7 \mathrm{ab}$ & 59.7 a & $29.8 \mathrm{a}$ & $33.0 \mathrm{a}$ \\
\hline UR & $68.5 \mathrm{~b}$ & $56.4 \mathrm{~b}$ & $68.3 \mathrm{~b}$ & $51.6 \mathrm{a}$ & $30.7 \mathrm{a}$ & $30.7 \mathrm{a}$ \\
\hline \multicolumn{7}{|l|}{$\mathrm{N}$ rate $^{\mathrm{w}}$} \\
\hline 100 & $62.4 \mathrm{~b}$ & $55.5 \mathrm{~b}$ & $62.6 \mathrm{~b}$ & $58.1 \mathrm{a}$ & $23.6 \mathrm{~b}$ & $24.8 \mathrm{~b}$ \\
\hline 200 & $84.5 \mathrm{a}$ & $70.6 \mathrm{a}$ & $83.6 \mathrm{a}$ & $61.1 \mathrm{a}$ & $38.6 \mathrm{a}$ & $41.7 \mathrm{a}$ \\
\hline $\mathrm{N}$ source & \multicolumn{6}{|c|}{$\operatorname{NR}(\%)^{\mathrm{v}}$} \\
\hline $\mathrm{AN}$ & $32.1 \mathrm{a}$ & $24.7 \mathrm{a}$ & $23.5 \mathrm{a}$ & $10.0 \mathrm{a}$ & $19.0 \mathrm{a}$ & $15.7 \mathrm{a}$ \\
\hline$\left(\mathrm{NO}_{3}\right)$ & (17.9) a & (14.1) a & (12.8) a & (5.8) a & (9.5) a & $(8.3) \mathrm{a}$ \\
\hline$\left(\mathrm{NH}_{4}\right)$ & $(14.2) \mathrm{b}$ & $(10.6) b$ & $(10.8) b$ & (4.2) a & (9.5) a & $(7.5) \mathrm{a}$ \\
\hline AS & $34.1 \mathrm{a}$ & $26.9 \mathrm{a}$ & $23.0 \mathrm{a}$ & $10.5 \mathrm{a}$ & $21.4 \mathrm{a}$ & $18.6 \mathrm{a}$ \\
\hline UR & $26.0 \mathrm{~b}$ & $17.5 \mathrm{~b}$ & $20.3 \mathrm{~b}$ & $5.7 \mathrm{~b}$ & $19.6 \mathrm{a}$ & $13.1 \mathrm{a}$ \\
\hline \multicolumn{7}{|l|}{$\mathrm{N}$ rate } \\
\hline 100 & $26.1 \mathrm{~b}$ & $24.5 \mathrm{a}$ & $22.4 \mathrm{a}$ & $8.7 \mathrm{a}$ & $21.4 \mathrm{a}$ & $16.1 \mathrm{a}$ \\
\hline 200 & $35.3 \mathrm{a}$ & $21.2 \mathrm{a}$ & $22.1 \mathrm{a}$ & $5.2 \mathrm{~b}$ & $18.6 \mathrm{a}$ & $15.5 \mathrm{a}$ \\
\hline
\end{tabular}

${ }^{\mathrm{z}}$ Values are the means of three, one-pot replications.

${ }^{\mathrm{y}} \mathrm{AN}=$ ammonium nitrate, $\mathrm{AS}=$ ammonium sulfate, and UR = urea.

${ }^{x}$ Mean separation within columns (for N source, AN source, or N rate) by Tukey's studentized range test, $P<0.05$.

${ }^{\mathrm{w}} \mathrm{kg} \cdot \mathrm{ha}^{-1}$ for $84 \mathrm{~d}$.

${ }^{v}$ Expressed as percentage of the applied $\mathrm{N}$.

system NR, defined as labeled fertilizer NR within both plant culture medium plus the combined NR in all plant organs (Table 4). Essentially all of the total system NR was in the plant system, with growing medium NR representing $<1 \%$ of the applied fertilizer $\mathrm{N}$. Following Expt. 1, total system NR for AS and AN averaged 78\% of the applied N, whereas NR for UR averaged only $66 \%$ of the applied fertilizer $\mathrm{N}$. The greater NR for AN and AS is not consistent with the suggestion that, since UR is less likely to leach, plant uptake would be greater with UR-N as compared with the more readily available and leachable $\mathrm{N}$ from AS and AN (Hesketh et al., 1995).

During Expt. 2, NR from AS and AN averaged 52\% as compared to only $98 \%$ from UR. Total system NR in Expt. 2 was likely limited by the reduced growth rate.

Overall $\mathrm{N}$ losses from the total system ranged from $21 \%$ to $34 \%$ of the applied, labeled $\mathrm{N}$, depending on $\mathrm{N}$ source, when the DM accumulation in clippings, verdure, and thatch plus roots was optimized, and when the growth represented a strong metabolic $\mathrm{N}$ sink (Expt. 1; Table 4). However, when bermudagrass was growing under conditions less favorable for top growth (Expt. 2), the reduced growth rate and $\mathrm{N}$ utilization combined to cause an approximate doubling of $\mathrm{N}$ losses ( $46 \%$ to $62 \%$ of the applied $\mathrm{N}$ ) as compared to the conditions of Expt. 1 (Table 4). Thus, during Expt. 2, the N losses represented a major unused $\mathrm{N}$ source in the system, particularly under UR fertilization.

While studies evaluating effects of late growing season $\mathrm{N}$ fertilization on N losses in turfgrass systems are limited (Geron et al., 1993), late-season $N$ application is practiced by many bermudagrass turf managers in the southern United States, with the aim of prolonging growth and color retention into the fall season and of accelerating the regreening process in the subsequent spring season (Goatley et al., 1994 and 1998). Our results indicate that about twice as much of the $\mathrm{N}$ applied in the late-season will not be used by the grass. Although we did not identify the lost $\mathrm{N}$ fractions, the unrecovered $\mathrm{N}$ could be subjected to various loss mechanisms, most notably $\mathrm{N}$ leaching and volatilization, assuming $\mathrm{N}$ applications are made with the soluble $\mathrm{N}$ sources and with the rates, frequencies, and environmental conditions used in this study.

Surprisingly, there was relatively little influence (or none at all) of $\mathrm{N}$ rate (100 or $200 \mathrm{~kg} \cdot \mathrm{ha}^{-1}$ for $84 \mathrm{~d}$ ) on $\mathrm{N}$ losses (Table 4). It is widely accepted that, in cool-season turfgrasses, the potential risk for $\mathrm{N}$ loss increases with increasing $\mathrm{N}$ rate (Hesketh et al., 1995), but as we show here in a warm-season turfgrass, the source of soluble $\mathrm{N}$ used, the season of $\mathrm{N}$ application, and the growth rate of the plant contribute toward that risk, even more so than $\mathrm{N}$ application rate under these conditions.

\section{Literature Cited}

Beard, J.B. and R.L. Green. 1994. The role of turfgrasses in environmental protection and their benefits to humans. J. Environ. Qual. 23:452460.

Bowman, D.C., J.L. Paul, and W.B. Davis. 1989. Nitrate and ammonium uptake by nitrogen-deficient perennial ryegrass and Kentucky bluegrass turf. J. Amer. Soc. Hort. Sci. 114:421-426.

Bremner, J.M. and R.D. Hauck. 1982. Advances in methodology for research on nitrogen transformations in soils, p. 467-502. In: F.J. Stevenson (ed.). Nitrogen in agricultural soils. Publ. 22, Amer. Soc. Agron., Madison, Wis.

Exner, M.E., M.E. Burbach, D.G. Watts, R.C. Sherman, and R.F. Spalding. 1991. Deep nitrate movement in the unsaturated zone of a simulated urban lawn. J. Environ. Qual. 20:658-662.

Gaussoin, R.E., A.A. Baltensperger, and B.N. Coffey. 1988. Response of 32 bermudagrass clones to reduced light intensity. HortScience 
Table 4. Nitrogen recovery (NR) by total system (plant plus growing medium), NR by the individual components of plant and growing medium, and estimated $\mathrm{N}$ losses (unaccounted fertilizer $\mathrm{N}$ ) in 'Tifgreen' hybrid bermudagrass fertilized with soluble sources of labeled ${ }^{15} \mathrm{~N}$. Plant system NR obtained by summation of individual organ components (Table 3). Growing medium NR determined as a single measurement at the end of $84 \mathrm{~d}$ (Eqs. 1-3). Nitrogen recovery and losses expressed as a percentage of the applied fertilizer $\mathrm{N}$ following $84 \mathrm{~d}{ }^{\mathrm{Z}}$

\begin{tabular}{|c|c|c|c|c|}
\hline \multirow[b]{2}{*}{$\begin{array}{l}\text { Main } \\
\text { factor }\end{array}$} & \multicolumn{4}{|c|}{$\mathrm{NR}(\%)^{\mathrm{y}}$} \\
\hline & $\begin{array}{c}\text { Total } \\
\text { system }\end{array}$ & $\begin{array}{c}\text { Plant } \\
\text { system }\end{array}$ & $\begin{array}{l}\text { Growing } \\
\text { medium }\end{array}$ & $\begin{array}{c}\mathrm{N} \\
\text { losses }(\%)^{y}\end{array}$ \\
\hline & & & & \\
\hline \multicolumn{5}{|l|}{$\mathrm{N}$ source $^{\mathrm{x}}$} \\
\hline AS & $79.3 \mathrm{a}^{\mathrm{w}}$ & $78.5 \mathrm{a}$ & $0.86 \mathrm{a}$ & $20.7 \mathrm{~b}$ \\
\hline $\mathrm{AN}$ & $75.7 \mathrm{ab}$ & $74.9 \mathrm{ab}$ & $0.77 \mathrm{a}$ & $24.3 \mathrm{ab}$ \\
\hline$\left(\mathrm{NO}_{3}\right)$ & $(40.7) \mathrm{a}$ & (40.2) a & $(0.48) \mathrm{a}$ & $(9.3) \mathrm{b}$ \\
\hline$\left(\mathrm{NH}_{4}\right)$ & $(35.0) \mathrm{b}$ & $(34.7) b$ & $(0.29) \mathrm{b}$ & $(15.0) \mathrm{a}$ \\
\hline UR & $66.4 \mathrm{~b}$ & $65.9 \mathrm{~b}$ & $0.52 \mathrm{~b}$ & $33.6 \mathrm{a}$ \\
\hline \multicolumn{5}{|l|}{$\mathrm{N}$ rate $^{\mathrm{v}}$} \\
\hline 100 & $70.7 \mathrm{a}$ & $70.0 \mathrm{a}$ & $0.68 \mathrm{a}$ & $29.3 \mathrm{a}$ \\
\hline 200 & $76.9 \mathrm{a}$ & $76.1 \mathrm{a}$ & $0.76 \mathrm{a}$ & $23.1 \mathrm{a}$ \\
\hline & \multicolumn{4}{|c|}{ Expt. 2} \\
\hline \multicolumn{5}{|l|}{$\mathrm{N}$ source } \\
\hline AS & $53.7 \mathrm{a}$ & $53.0 \mathrm{a}$ & $0.73 \mathrm{a}$ & $46.3 \mathrm{~b}$ \\
\hline $\mathrm{AN}$ & $51.1 \mathrm{a}$ & $50.3 \mathrm{a}$ & $0.79 \mathrm{a}$ & $48.9 \mathrm{ab}$ \\
\hline$\left(\mathrm{NO}_{3}\right)$ & $(27.3) \mathrm{a}$ & $(28.2) \mathrm{a}$ & $(0.44) \mathrm{a}$ & $(22.7) b$ \\
\hline$\left(\mathrm{NH}_{4}\right)$ & $(23.8) b$ & $(22.1) \mathrm{b}$ & $(0.35) \mathrm{a}$ & (26.2) a \\
\hline UR & $38.5 \mathrm{~b}$ & $38.0 \mathrm{~b}$ & $0.56 \mathrm{a}$ & $61.5 \mathrm{a}$ \\
\hline \multicolumn{5}{|l|}{$\mathrm{N}$ rate } \\
\hline 100 & $51.7 \mathrm{a}$ & $51.0 \mathrm{a}$ & $0.71 \mathrm{a}$ & $48.3 \mathrm{~b}$ \\
\hline 200 & $43.0 \mathrm{~b}$ & $42.3 \mathrm{a}$ & $0.66 \mathrm{a}$ & $57.0 \mathrm{a}$ \\
\hline
\end{tabular}

${ }^{\mathrm{z}}$ Values are the means of three, one-pot replications.

yexpressed as percentage of the applied $\mathrm{N}$.

${ }^{\mathrm{x}} \mathrm{AS}=$ ammonium sulfate, $\mathrm{AN}=$ ammonium nitrate, and $\mathrm{UR}=$ urea.

${ }^{w}$ Mean separation within columns (for $\mathrm{N}$ source, AN source, or $\mathrm{N}$ rate) by Tukey's studentized range test, $P<0.05$.

${ }^{\mathrm{v}} \mathrm{kg} \cdot \mathrm{ha}^{-1}$ for $84 \mathrm{~d}$.

23:178-179.

Gavlak, R.G., D.A. Horneck, and R.O. Miller. 1994. Plant, soil, and water reference methods for the western region. W. Reg. Ext. Publ. 125.

Geron, C.A., T.K. Danneberger, S.J. Traina, T.J. Logan, and J.R. Street. 1993. The effects of establishment and fertilization practices on nitrate leaching from turfgrass. J. Environ. Qual. 22:119-125.

Goatley, J.M., Jr., V.L. Maddox, and K.L. Hensler. 1998. Late-season applications of various nitrogen sources affect color and carbohydrate content of 'Tiflawn' and Arizona common bermudagrass. HortScience 33:692-695.

Goatley, J.M., Jr., V. Maddox, D.J. Lang, and K.K. Crouse. 1994. 'Tifgreen' bermudagrass response to late-season application of nitrogen and potassium. Agron. J. 86:7-10.

Gross, C.M., J.S. Angle, and M.S. Welterlen. 1990. Nutrient and sediment losses from turfgrass. J. Environ. Qual. 19:663-668.

Hanan, J.J. 1998. Greenhouses-Advanced technology for protected horticulture. CRC Press, Boca Raton, Fla.

Hesketh, E.S., R.J. Hull, and A.J. Gold. 1995. Estimating non-gaseous nitrogen losses from established turf. J. Turfgrass Mgt. 1:17-30.

Janzen, H.H., J.B. Bole, V.O. Biederbeck, and A.E. Slinkard. 1990. Fate of $\mathrm{N}$ applied as green manure or ammonium fertilizer to soil subsequently cropped with wheat at three sites in western Canada. Can. J. Soil Sci. 70:313-323.

Joo, Y.K., N.E. Christians, and A.M. Blackmer. 1991. Kentucky bluegrass recovery of urea-derived nitrogen-15 amended with urea inhibitor. Soil Sci. Soc. Amer. J. 55:528-530.

Marousky, F.J., A.E. Dudeck, L.B. McCarty, and S.F. Anderson. 1992. Influence of daylength and fertility on growth of bermudagrass cultivars. Proc. Fla. State Hort. Soc. 105:236-238.
Marschner, H. 1995. Mineral nutrition of higher plants. Academic, New York. McCaslin, B.D., M.R. Hughes, and A.A. Baltensperger. 1989. Nitrogen fertilization $\times$ genotype interactions influence bermudagrass turf quality characteristics. J. Amer. Soc. Hort. Sci. 114:65-68.

Miltner, E.D., B.E. Branham, E.A. Paul, and P.E. Rieke. 1996. Leaching and mass balance of ${ }^{15} \mathrm{~N}$-labeled urea applied to a Kentucky bluegrass turf. Crop Sci. 36:1427-1433.

Petrovic, A.M. 1990. The fate of nitrogenous fertilizers applied to turfgrass. J. Environ. Qual. 19:1-14.

SAS Institute, Inc. 1990. SAS/STAT user's guide. vol. 2. GLMVARCOMP. SAS Inst., Cary, NC.

Snyder, G.H. and E.O. Burt. 1985. Nitrogen sources for fertigation of bermudagrass turf, p. 557-565. In: F. Lemaire (ed.). Proc. 5th Intl. Turfgrass Res. Conf., Avigon, France. 1-5 July 1985.

Starr, J.L. and H.C. DeRoo. 1981. The fate of nitrogen fertilizer applied to turfgrass. Crop Sci. 21:531-536.

Thimijan, R.W. and R.D. Heins. 1983. Photometric, radiometric, and quantum light units of measure: A review for procedures for interconversion. HortScience 18:818-822.

Trenholm, L.E., A.E. Dudeck, J.B. Sartain, and J.L. Cisar. 1998. Bermudagrass growth, total nonstructural carbohydrate concentration, and quality as influenced by nitrogen and potassium. Crop Sci. 38:168174.

Turner, T.R. and N.W. Hummel, Jr. 1992. Nutritional requirements and fertilization, p. 387-439. In: D.V. Waddington, R.N. Carrow, and R.C. Shearman (eds.). Turfgrass. Amer. Soc. Agron.-Crop Sci. Soc. Amer.Soil Sci. Soc. Amer. Monogr. 32.

Youngner, V.B. 1959. Growth of U-3 bermudagrass under various day and night temperatures and light intensities. Agron. J. 51:557-559.

U.S. Census Bureau. 1999. Http://www.census.gov. 16 Apr. 1999. 